University of Nebraska - Lincoln

DigitalCommons@University of Nebraska - Lincoln

Nebraska Cooperative Fish \& Wildlife Research Nebraska Cooperative Fish \& Wildlife Research Unit -- Staff Publications

2002

\title{
Assessing state-wide biodiversity in the Florida Gap analysis project
}

L. G. Pearlstine

University of Florida, pearlstn@ufl.edu

S. E. Smith

University of Florida

L. A. Brandt

U.S. Fish and Wildlife Service

C. R. Allen

South Carolina Cooperative Fish and Wildlife Research Unit, callen3@unl.edu

W. M. Kitchens

U.S. Geological Survey

See next page for additional authors

Follow this and additional works at: https://digitalcommons.unl.edu/ncfwrustaff

Part of the Other Environmental Sciences Commons

Pearlstine, L. G.; Smith, S. E.; Brandt, L. A.; Allen, C. R.; Kitchens, W. M.; and Stenberg, J., "Assessing statewide biodiversity in the Florida Gap analysis project" (2002). Nebraska Cooperative Fish \& Wildlife Research Unit -- Staff Publications. 61.

https://digitalcommons.unl.edu/ncfwrustaff/61

This Article is brought to you for free and open access by the Nebraska Cooperative Fish \& Wildlife Research Unit at DigitalCommons@University of Nebraska - Lincoln. It has been accepted for inclusion in Nebraska Cooperative Fish \& Wildlife Research Unit -- Staff Publications by an authorized administrator of DigitalCommons@University of Nebraska - Lincoln. 


\section{Authors}

L. G. Pearlstine, S. E. Smith, L. A. Brandt, C. R. Allen, W. M. Kitchens, and J. Stenberg 


\title{
Assessing state-wide biodiversity in the Florida Gap analysis project
}

\author{
L. G. Pearlstine ${ }^{\dagger^{*}}$, S. E. Smith ${ }^{\ddagger}$, L. A. Brandt ${ }^{\S}$, C. R. Allen", \\ W. M. Kitchens $\|$ and J. Stenberg"
}

${ }^{\dagger}$ Assistant Scientist, Department of Wildlife Ecology and Conservation, University of Florida, Gainesville, FL 32611, USA

${ }^{\ddagger}$ Associate Professor, Department of Civil Engineering, University of Florida, Gainesville, FL 32611, USA

$\S$ Senior Wildlife Biologist, A. R. M. Loxahatchee National Wildlife Refuge, U.S. Fish and Wildife Service, Boynton Beach, FL 33437, USA

"Unit Leader, South Carolina Cooperative Fish and Wildlife Research Unit, Clemson, SC 29634, USA

"Research Scientist, Florida Cooperative Fish and Wildlife Research Unit, U.S. Geological Survey, Gainesville, FL 32611, USA

\# Environmental Scientist III, St Johns River Water Management District, Palatka, FL 32178, USA

Received 27 April 2001; accepted 2 January 2002

\begin{abstract}
The Florida Gap (Fl-Gap) project provides an assessment of the degree to which native animal species and natural communities are or are not represented in existing conservation lands. Those species and communities not adequately represented in areas being managed for native species constitute 'gaps' in the existing network of conservation lands. The United States Geological Survey Gap Analysis Program is a national effort and so, eventually, all 50 states will have completed it. The objective of Fl-Gap was to provide broad geographic information on the status of terrestrial vertebrates, butterflies, skippers and ants and their respective habitats to address the loss of biological diversity. To model the distributions and potential habitat of all terrestrial species of mammals, breeding birds, reptiles, amphibians, butterflies, skippers and ants in Florida, natural land cover was mapped to the level of dominant or co-dominant plant species. Land cover was classified from Landsat Thematic Mapper (TM) satellite imagery and auxiliary data such as the national wetlands inventory (NWI), soils maps, aerial imagery, existing land use/land cover maps, and on-the-ground surveys. Wildlife distribution models were produced by identifying suitable habitat for each species within that species' range. Mammalian models also assessed a minimum critical area required for sustainability of the species' population. Wildlife species richness was summarized against land stewardship ranked by an area's mandates for conservation protection.

$\circlearrowleft 2002$ Elsevier Science Ltd. All rights reserved.
\end{abstract}

Keywords: biodiversity, land cover classification, habitat modeling, gap analysis program, Florida.

\section{Introduction}

Florida is a state with diverse and unique species and landscapes. Its geographic position, spanning

* Corresponding author. E-mail: pearlstn@ufl.edu latitudes from temperate to semi-tropic climates, plays a major role in shaping its biotic assemblages. Florida is mainly a large peninsula of North America that extends about $650 \mathrm{~km}$ between the Atlantic Ocean and the Gulf of Mexico. These relatively warm climatic influences create humid conditions that support lush and diverse vegetation. 
Even the central portions of the peninsula and panhandle are influenced by tropical conditions through southerly wind patterns.

Anthropogenic disturbance from population growth is threatening the existence of some Florida ecosystems and the sustainability of many others. Between 1960 and 2000, the population of the state more than tripled. In the decade between 1990 and 2000 the population of Florida increased by more than 3 million. (Bureau of Census, 1960; Bureau of Census, 1990; Bureau of Census, 2000). The Federal government owns only about $9 \%$ of Florida's landmass with state and other government entities owning very small amounts of land. The rest is privately held.

Expanding human habitation comes at the expense of natural habitat. It has resulted in habitat loss, fragmentation, conflict over water needs and use, and increasing recreational pressures on the ecosystems. When the Florida Fish and Wildlife Conservation Commission published the first statewide analysis of land covers, wildlife distributions and areas needing conservation protection in 1994 (Cox et al., 1994), less than 10\% of the State's historical longleaf pine natural community remained, and less than 5\% of the State's rare pine rocklands natural community remained. Florida is still diverse in both plants and animals, but the persistence of habitats will depend on better and scientifically based planning for both resources and growth together with conservation action.

The mission of the US National Gap Analysis Program (Gap) is to mitigate wildlife conservation problems by 'providing an assessment of the essential biotic elements (plant communities and native animal species) and to facilitate the application of this information to land management activities' (Scott et al., 1987; Scott and Jennings, 1994). Gap analysis relies on maps of dominant natural land cover types as the most fundamental spatial component of the analysis (Scott et al., 1993) for terrestrial environments.

\section{Methods}

\section{Land cover classification}

Land cover was classified to an aggregation of the National Vegetation Classification Scheme (NVCS) (The Nature Conservancy, 1997). The NVCS is an ecologically based, hierarchical classification that treats all existing terrestrial vegetation types in one system. The Nature Conservancy (TNC) and the
Natural Heritage Network (Grossman et al., 1994) have been improving upon this system. The basic assumptions and definitions for this classification system have been described by Jennings (1993). The basis for aggregating of the NVCS for Gap analysis in the Southeast United States is presented in Pearlstine and McKerrow (1999).

Classification was accomplished using 1992-94 Landsat Thematic Mapper (TM) satellite imagery and auxiliary sources of data as described below and in Figure 1. The classification approach involved preparation and transformation of the imagery, stratification, and iterative, unsupervised classification. Most of the scenes used to cover the state of Florida are from the winter of 1993 or spring 1994. Images for two of the scene areas were available from both spring and winter, and so were used in a multi-temporal analysis to aid the classification.

Water Management District land use/land cover maps were overlaid onto the satellite images to check the geometric consistency of the images. If positional errors were present, an affine transformation and nearest-neighbor resampling were used to co-register the imagery with the land use/land cover maps.

Atmospheric haze existed in borne of the images and was removed in the pre-processing stage of the image processing. Crist et al. (1984) presented a technique that we used for minimizing the effects of haze by subtracting the image from the fourth spectral band of a tasseled cap transformation. The tasseled cap transformation's fourth band corresponds with haze features present in the image and has little or no effect on portions of the image where haze is not present.

The first three spectral bands of the tasseled cap transformation correspond to 'brightness', 'greenness' and 'wetness' in the image and have been shown to be effective for improving classification results (Crist, 1984). These three transformed bands and bands 2, 3, 4, and 5 of the original TM image were combined for the final image used for classification.

For the two scenes with spring and winter images, the images were co-registered and normalized before being combined. Normalization was necessary to correct for differences in sensor offset and gain, and scene illumination. The difference in overall brightness between the images was normalized using a linear image regression process as described in the ERDAS Field Guide (ERDAS, 1999) and Jensen (1996).

This approach is well suited for multi-temporal analysis where care must be taken not to adjust the image for the seasonal variation of vegetation. 


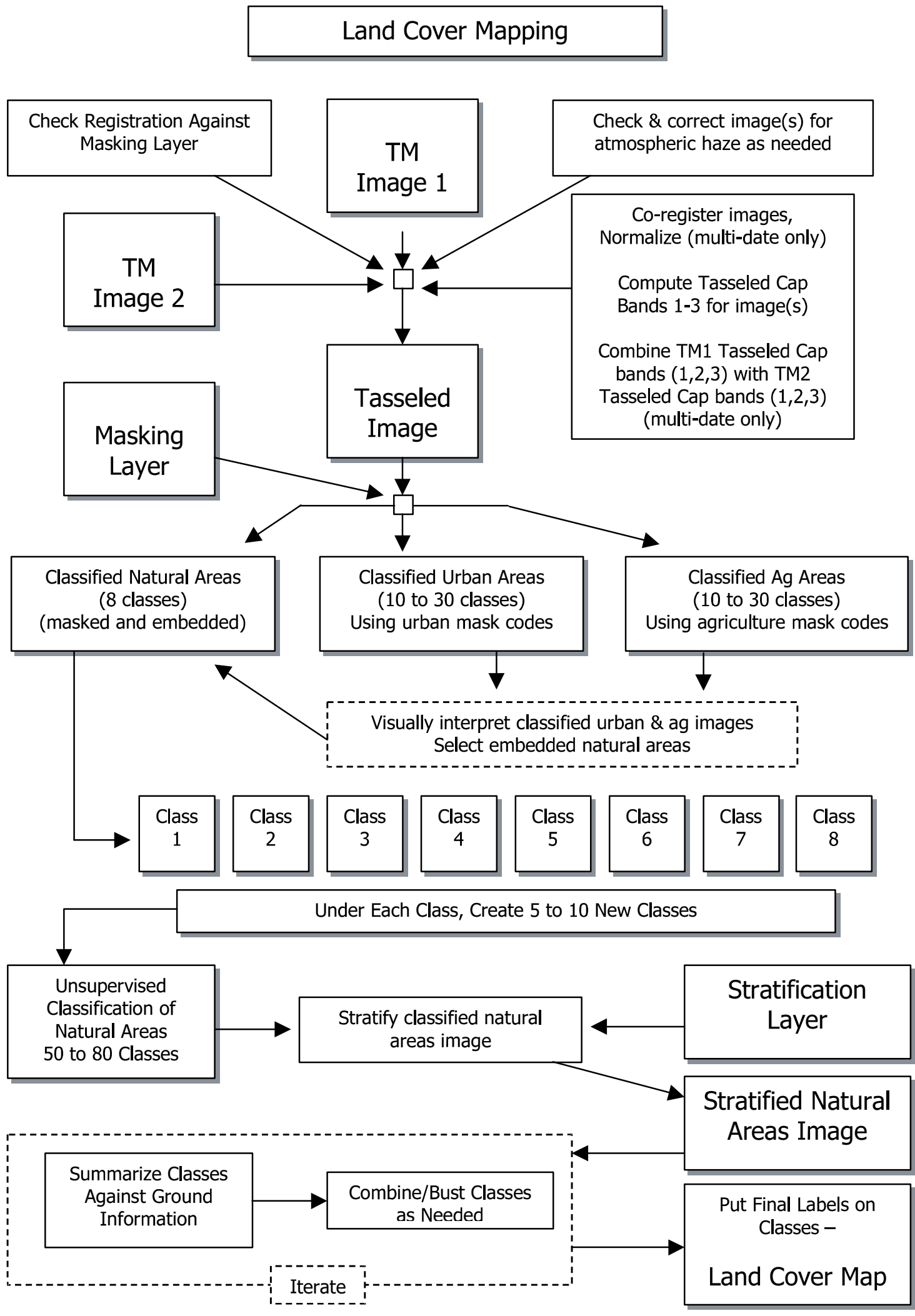

Figure 1. Land cover mapping flow chart. 
A regression model to account for these differences was created by first identifying several 'bright' and 'dark' objects in each scene and, for each band, recording the digital number (DN). The darkest pixel was assigned the DN 'zero'. Examples of 'dark' objects were uniform non-turbid man-made lakes and coniferous forests. Examples of 'bright' objects were airport runways, large roads, beaches, and dry exposed soils.

Once these values were compiled, a linear regression model was computed with the darker of the two images (i.e., the image with the overall lower average DN for all bands and all pixels) was assigned to the $\mathrm{x}$ variable. No negative numbers at the pixelto-pixel level existed due to the fact that the darkest pixel's DN was set to zero. This insured that positive corrections were made such that when applied, no negative numbers resulted in the output image. For each band, a linear regression model and an associated scatter plot were computed. If the model had a correlation coefficient ( $r$ ) higher than $95 \%$ and the scatter plot did not have significant outliers, the linear model was used. When outliers were detected, they were removed and the regression model was recomputed.

Urban and agricultural areas of a satellite image typically have a much wider variance of $\mathrm{DN}$ values that are found in naturalareas. As a result, signatures describing urban and agricultural areas can often obscure or confuse discrimination of natural vegetation types. To minimizethose effects, theimages were stratified in 'natural areas' and 'developed areas' by masking out urban and agricultural areas with state Water Management District land use/land cover maps. Becuase these land use maps often delineate 'developed' classes that contain embedded natural areas that we wanted to retain, the developed area image was classified using the 'ISODATA' routine in the ERDAS remote sensing software (ERDAS, 1999). Classes that appeared to represent natural areas occurring within the developed areas were identified and the spectral image under those classes was reassigned to the natural areas image.

The natural areas image was stratified once more before beginning classification. This stratification took advantage of existing soils and wetlands maps to further reduce the variance of image $\mathrm{DN}$ values that are considered together. USDA National Soil Survey Center digital county-level soil maps were aggregated to 13 broad classes. US Fish and Wildlife Service National Wetlands Inventory maps were aggregated to 18 classes. Neither map series covered the entire state, so, depending on availability, one or the other or both were used for stratification over an entire scene. Using these digital vector coverages directly to mask out parts of the image would create a classification with hard boundaries that are artifacts of the vector coverage rather than changes in the reflectance values in the image. In order to create more realistic boundaries between classes, contiguous, spectrally similar pixels were treated as a group (Figure. 2). To accomplish this, an unsupervised classification was performed on the entire natural areas image, creating a classified image with 50 to 80 classes. When the map used for stratification was laid over the classified image, contiguous pixels classified to the same value that fell with a majority in one strata stayed together with that strata rather than being split on the boundary line. This then became the mask to split the image into many separate natural area images, each representing the part of a single scene under one strata.

The final step was the actual classification of the image subscenes into labeled vegetation classes. This was an iterative process of 'ISODATA' clustering and minimum distance classification. Following classification, labeling of the resulting classes was first attempted with the assistance of ground truth information, auxiliary data sources, low altitude aerial videography and aerial digital imagery. When a class represented more than one predominate

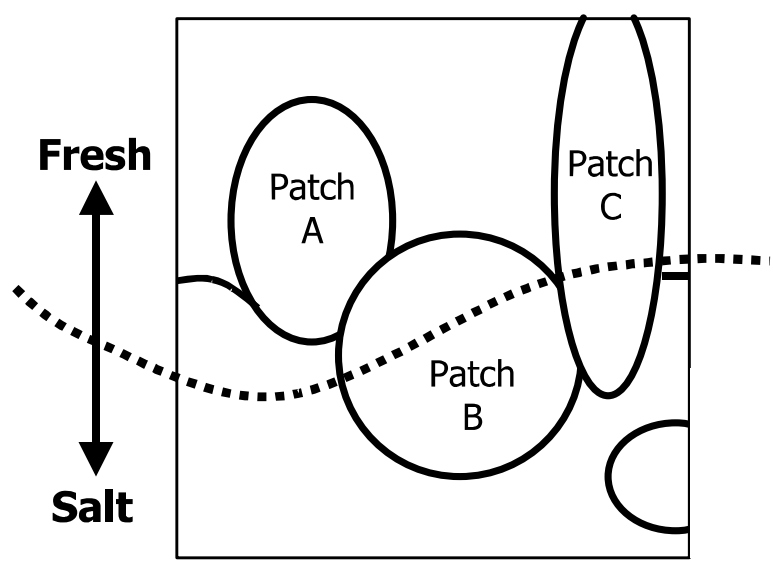

Figure 2. Retention of community shape when stratifying a classified satellite image by another dataset. In this synthetic figure, National Wetlands Inventory (NWI) mapped data is used to stratify areas as either freshwater of saltwater communities. The land cover type in Patch A is entirely within the NWI freshwater boundary. Patch B, however, falls across the NWI boundary. Because the majority of the patch is within saltwater, the whole patch is considered to be a saltwater community. Likewise, Patch C is entirely defined as freshwater even though part of the patch extends beyond the NWI boundary. In this fashion, the final boundary between fresh and saltwater communities generally follows the drawn NWI information, but is influenced by the found patterns classified from the satellite image. 
vegetation type, the class was further subdivided by new classification just within the target class or by decision rules using auxiliary mapped data not used in the initial stratification. This procedure was repeated until all the classes could be identified to a land cover type.

The supplementation of ground survey data with aerial videography was accomplished in south Florida by the mounting of two $8 \mathrm{~mm}$ video recorders on a window mount in a light fixed-wing aircraft. One of the video cameras recorded an approximately $30 \times 30 \mathrm{~m}$ swath along the flightline, often providing the resolution needed for species level identification. A wider-angle lens on the other video camera recorded a swath of approximately $400 \mathrm{~m}$ to provide a landscape context to relationship to the zoomed-in video camera. Slaymaker (1996) provides a detailed description of the configuration.

A GPS aboard the aircraft and differential postprocessing provided georeferenceing for the image frame that tests suggested was typically within $60 \mathrm{~m}$ of the true ground position. Videography was flown in predominately east-west transects approximately every 7.5 min of latitude from the lower Florida Keys to just south of Orlando (see Figure 3 for place locations). When the sequence of transects reached central and north Florida, a Kodak DCS 420 color infrared digital camera was substituted for the zoomed-in video camera to improve image resolution. The infrared imagery also aided in vegetation species identification. Additional, real-time FM differential correction via an Accupoint receiver and a Watson Industries attitude and heading reference system reduced positional errors in the image frames to $30 \mathrm{~m}$.

\section{Prediction of animal species distributions and species richness}

The purpose of the vertebrate species maps was to provide accurate information of the predicted distribution of individual native species in their geographic ranges, and to overlay individual predicted distributions to produce an overall map of species richness for Florida. Species distributions were modeled using the Environment Systems Research Institute's Arc/Info software by estimating the geographic range of each species and identifying land covers suitable for the species' habitat within its range. A refinement of the mammalian species models was to also estimate the minimum critical areas of habitat necessary to sustain a viable population (Allen et al., 2001).
The geographic distribution for mammals was determined by surveying sixteen state and national museums that included Florida vertebrates, as well as a review of published sources (e.g., Blair, 1935; Hamilton, 1941; Pournelle, 1950; Sherman 1953; Pearson, 1954; Starner, 1956; Chapman and Feldhamer, 1982; Layne, 1984; Humphrey, 1992). Bird species ranges were based upon the Florida breeding bird atlas (Kale et al., in press). Reptile and amphibian (herpetofauna) ranges were determined from a statewide occurrence database (Moler, 1999). Butterfly ranges were determined from Opler (1999). Ant ranges were determined primarily from published sources, and from the unpublished data of D. P. Wojcik (1999). Experts of the respective taxa reviewed resulting county-level range maps for each species.

Animal distribution data for the state of Florida was almost exclusively at the level of counties. Thus, our original distributions for the modeled species were made at the county-level. Using county boundaries as geographic units for species predictions would have overestimated distributions of species in cases where a species' range extended only partly into the county. To reduce this problem, and to facilitate compatibility with wildlife range coverages generated by adjacent states, the county-level distributions were joined with a US Environmental Protection Agency hexagon grid system to provide distribution coverage for each species as shown by these equal-area, 640 ha hexagonal map units. Advantages to using the hexagon grid include its equal area sampling structure, its independence from political and administrative boundaries (resulting in more consistent mapping of animal distributions), and its hierarchical structure which can facilitate increasing or decreasing grid densities in future analyses (White et al., 1992).

Species habitat relationships were determined from extensive examination of primary literature as well as taxa-specific treatments and unpublished reports. These sources are available on the Florida Gap Analysis Project web site: http://www.wec. ufl.edu/coop/Gap. Sources sometimes presented contradictory statements concerning wildlife relationships of particular species. In these cases we used the sources most proximate to or in Florida over other sources, and more recent sources over older sources. Habitat use data for each species was then used to build a species-by-habitat matrix for each taxa (mammals, birds, herpetofauna, butterflies and ants). These matrices recorded predicted the presence or absence of each species in the 71 land cover types that make up the Florida land cover map. 


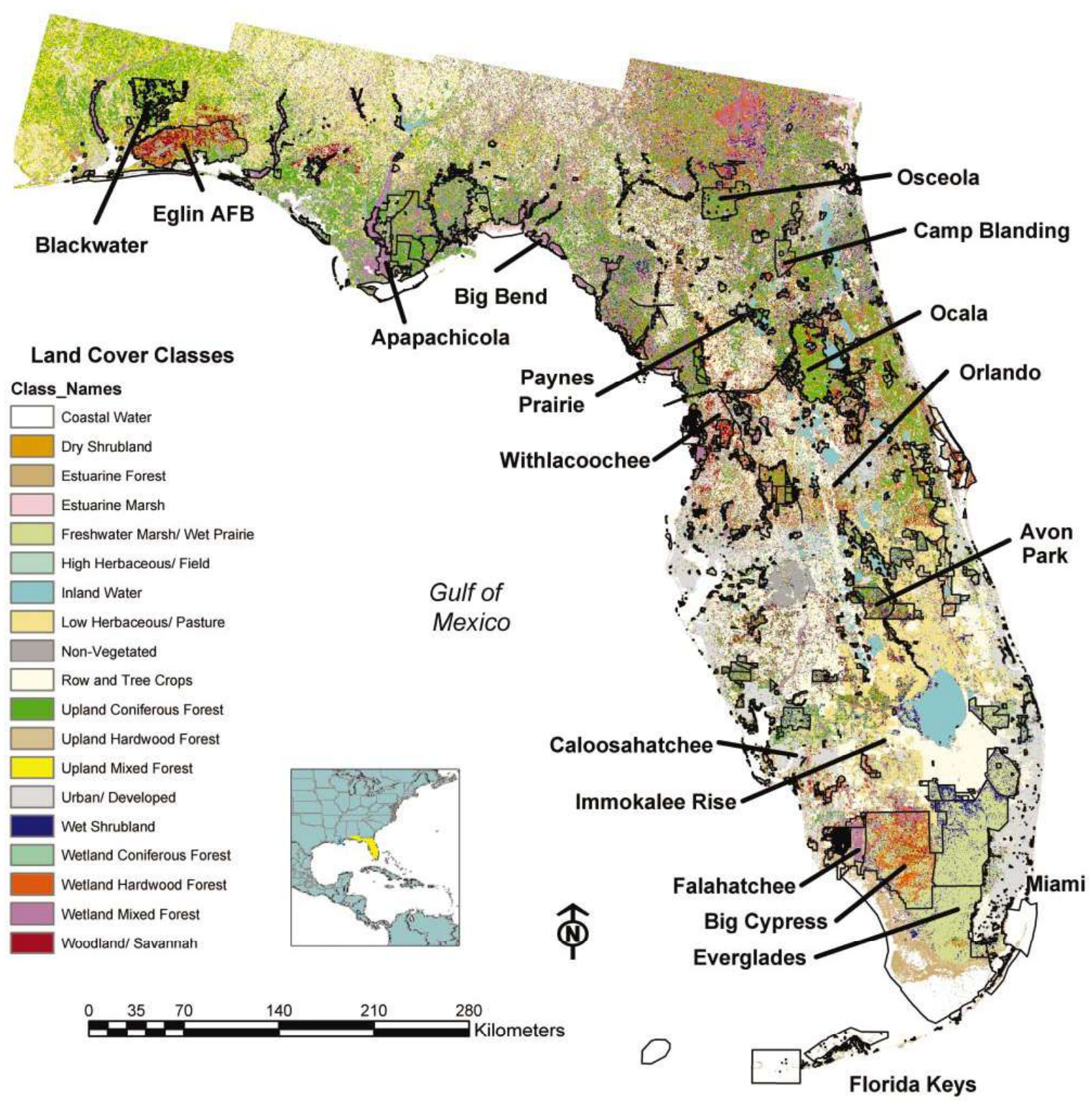

Figure 3. Florida land cover classification. Conservation land boundaries are overlaid as black lines. Place names shown are those places referred to in the text. The State of Florida study area is indicated in yellow on the insert map. Insert map source: ESRI Online Data.

In addition, listed species and non-indigenous species were assigned codes specific to their status. Listed species included species that were 'listed' as state or federally endangered, threatened or species of special concern (Florida Game and Fresh Water Fish Commission, 1997). This allowed for comparison of patterns of species richness among listed species, secure native species, and non-indigenous introduced or invasive species.
Predicted species models that are based primarily upon habitat (land cover classes) fail to incorporate many of the basic ecological characteristics of those species. One issue is that home range sizes of animals occupying the same landscape may vary by several orders of magnitude. For example, the home range of the golden mouse (Ochrotomys nuttali) in the southeastern United States is approximately 0.50 ha. In contrast, the home range 
of the striped skunk (Mephitis mephitis) may exceed 300 ha, and the home range of the Florida panther (Felis concolor coryi) may exceed 50000 ha.

If these species co-occurred in a given favorable land cover class with an extent (patch size) of 1000 ha, embedded in a matrix of unfavorable habitat, mapping all three species as present may not reflect the more specific life history characteristics of each. A Florida panther could not maintain a viable population in a habitat patch of $1000 \mathrm{ha}$, and the area requirements for a population of striped skunks would only be marginally met. However, 1000 ha would encompass a viable population of most species with small home ranges. On high-resolution maps, commission error - the chance of erroneously including an animal in a habitat that cannot support it-are likely to be high when creating species models based simply on species-habitat associations. With this in mind, we incorporated information on the home range of the mammals of Florida to estimate minimum critical areas needed to support minimum viable populations for each mammal species (Allen et al., 2001). Incorporating home range should increase the accuracy of species models by reducing the commission error rate.

The home range and dispersal distances of terrestrial Florida mammals were determined from extensive literature reviews. We preferentially used estimates from studies in Florida, but where home range or dispersal estimates specific to Florida were not available we used estimates from nearby locations. Home range estimates were used to calculate the area required to support a minimum viable population. For our purposes, we crudely defined MVP as being equal to 50 individuals, the estimated minimum number of individuals necessary to persist despite demographic stochasticity (Shaffer, 1981). Note that we do not assume that 50 is the 'real' minimum viable population size for mammals, nor that a species' minimum viable population can be precisely defined throughout its range, rather we chose this as a conservative value. Multiplying home range estimates by 25 calculated the minimum critical area required to support a minimum viable population for each species of 50 individuals dividing by two. Halving the number we multiply home range estimates by accounted for intersexual overlap among home ranges. Inter and intra-sexual home range overlap varies considerably among species; we chose complete overlap between sexes to produce conservative comparative models. No attempt was made to determine minimum critical area or dispersal distances for bat species.

\section{Land stewardship}

GIS boundaries and attributes for the stewardship of Florida conservation lands were provided by the Florida Natural Areas Inventory (FNAI). FNAI identifies as conservation lands any property that has a significant portion of its land area undeveloped and that has a professional manager or managing agency capable of protecting important elements of ecological diversity. Additionally, the land will have a legal mandate to manage and protect important ecological resources, even if that mandate is not the primary mission of the agency. Therefore, certain parks such as historical parks that do not have significant natural areas are not considered a conservation land. Likewise, military installations, which have a primary purpose of national defense but are also mandated by federal action to protect important natural resources, are considered a conservation land.

FNAI staff also produced the GAP protection status rankings for each area in the land stewardship database following the criteria of Scott and Jennings (1994). The four classes in the GAP protection status rankings are defined in Table 1 . Information used to develop the GAP protection status was mostly derived from the legal requirements of different land management categories (e.g., national forests are legally mandated to manage by multiple use, which lessens the protection a national forest affords biodiversity, versus national parks are which mandated to protect natural systems, which ensures that the protection of biodiversity is given highest priority). FNAI augmented this approach and also used FNAI's knowledge of the specific management activities on conservation lands to tailor the protection status to the current management activities on-site.

\section{Results}

\section{Land cover mapping}

Table 2 presents the frequency of occurrence of each land cover type for the state of Florida in square kilometers, and percent of the state's total area represented by the mapped type. The majority of Florida is in Mesic-Hydric Pine Forest land cover $(18 \%)$, forested swamp (14\%) or agriculture $(23 \%$, including pasture). The agricultural land use is primarily converted pinelands. The proportion of Mesic-Hydric Pine Forest that is in plantation farming was not determined. The combined forested 
Table 1. Protection status rankings for areas mapped as being managed with conservation objectives. Status categories were not applied to all lands of Florida

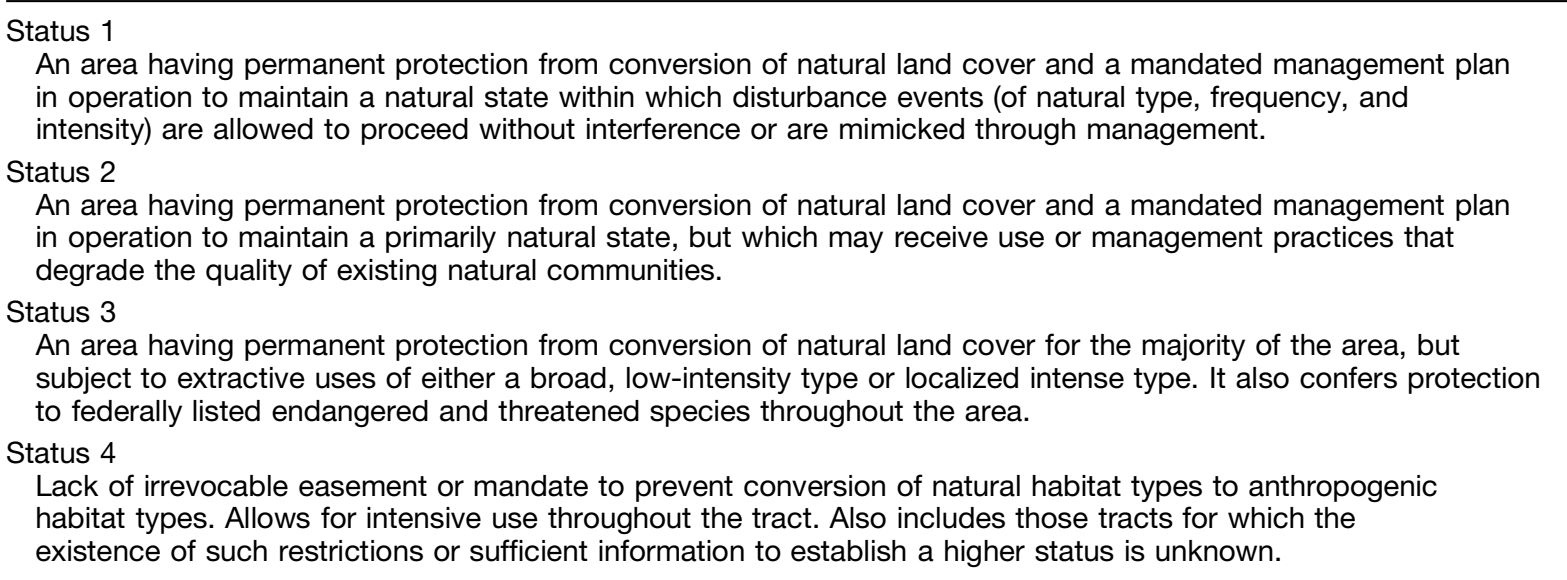

swamp classes are Tropical/subtropical Swamp Forest, Bay/Gum/Cypress, Loblolly Bay Forest, Swamp Forest, and Cypress Forest. Xeric shrub, Sandhill and sand pine comprise another $4 \%$ of the state, urban classes and freshwater marsh, primarily in southern Florida, contribute another $8 \%$ each to the state's land covers. The small percentages of each of the individual land cover classes listed in Table 2 are indicative of the heterogeneity of Florida's landscape. Because 71 classes are difficult to present in a figure, Figure 3 is a nineteen-class aggregation of the final land cover classification. Land stewardship boundaries are overlain to illustrate the patterns and extent of land cover diversity in conservation holdings. Table 3 summarizes the proportion of the state within each of the protection status areas.

As would be expected because of the low proportion of the state in status 1 protection, none of the state's land covers have a high percentage of their area contained within these categories. Status 2 lands, on the other hand, contain a high proportion of the state's mangroves, sawgrass marsh, and muhly marsh because of their occurrence in the south Florida everglades parks and preserves. Sandhill, wiregrass, sand pine, mesichydric pine, mixed pine/oak, forested swamplands of north and central Florida, and the dry prairies of mostly south central Florida are poorly represented in status 2 lands. These same classes are associated with the highest concentrations of species richness in Florida. Most of these classes are better represented within protection status 3 lands.

\section{Species richness}

Species richness for mammals, breeding birds, reptiles and amphibians, butterflies, ants and all species combined are shown in Figures 4-9. Land stewardship boundaries are overlain on each figure.

\section{Mammals}

The pine/oak and sandhill communities in the panhandle of Florida potentially support the highest diversity of mammals (Figure 4). The GAP status 3 lands in Eglin Air Force Base, Withlacoochee State Forest and Ocala National Forest, are characteristic of this communities. Sand pine, mesic pine, swamp forest and cypress in the panhandle through central Florida follow closely behind with species counts in the low thirties. In broad general terms, potential mammal species richness varies along a north-south gradient, and is highest in northern Florida and lowest in southern Florida. This pattern probably is indicative of a decrease in available habitat types, rather than a peninsula effect.

In southern Florida, the highest species richness is in southern Florida slash pine, dry prairie, swamp forests, and pine rocklands where the maximum number of mammalian species is in the low twenty's. These areas include lands in and around Avon Park Bombing Range, Fakahatchee Strand State Preserve, and lands north of the Caloosahatchee River. 
Table 2. Land cover frequency

\begin{tabular}{|c|c|c|c|}
\hline Code & Class name & Area (sq km) & $\%$ Total \\
\hline 1 & Open water & $5675 \cdot 21$ & 3.22 \\
\hline 2 & Tropical hardwood hammock formation & $210 \cdot 38$ & 0.12 \\
\hline 3 & Semi-deciduous tropical/subtropical swamp forest & 460.57 & 0.26 \\
\hline 4 & Xeric-mesic live oak ecological complex & 1363.98 & 0.77 \\
\hline 5 & Mesic-hydric live oak/sabal palm ecological complex & 392.30 & 0.22 \\
\hline 6 & Bay/gum/cypress ecological complex & $5279 \cdot 64$ & 3.00 \\
\hline 7 & Loblolly bay forest & 1393.43 & 0.79 \\
\hline 8 & Cajeput forest compositional group & 35.32 & 0.02 \\
\hline 9 & Mixed mangrove forest formation & $1085 \cdot 17$ & 0.62 \\
\hline 10 & Black mangrove forest & 67.91 & 0.04 \\
\hline 11 & Red mangrove forest & 269.78 & 0.15 \\
\hline 12 & Casuarina forest & 4.35 & 0.00 \\
\hline 13 & South Florida slash pine forest & 382.66 & 0.22 \\
\hline 14 & Sand pine forest & 1421.36 & 0.81 \\
\hline 15 & Xeric-mesic mixed pine/oak forest ecological complex & 10512.39 & 5.97 \\
\hline 16 & Mesic-hydric pine forest compositional group & 30878.57 & 17.53 \\
\hline 17 & Swamp forest ecological complex & $10049 \cdot 82$ & 5.70 \\
\hline 18 & Cypress forest compositional group & $6034 \cdot 24$ & 3.42 \\
\hline 19 & Mixed evergreen Cold-deciduous hardwood forest & 5532.42 & 3.14 \\
\hline 20 & Buttonwood woodland & 134.63 & 0.08 \\
\hline 21 & Mixed mangrove woodland & $62 \cdot 71$ & 0.04 \\
\hline 22 & Black mangrove woodland & 11.63 & 0.01 \\
\hline 23 & Red mangrove woodland & $26 \cdot 18$ & 0.01 \\
\hline 24 & Live oak woodland & 1061.02 & 0.60 \\
\hline 25 & Florida slash pine woodland & 496.99 & 0.28 \\
\hline 26 & Sandhill ecological complex & 4697.66 & 2.67 \\
\hline 27 & $\begin{array}{l}\text { Broad-leaved evergreen and mixed evergreen/ } \\
\text { cold-deciduous shrubland compositional group }\end{array}$ & 921.69 & 0.52 \\
\hline 28 & $\begin{array}{l}\text { Flooded broad-leaved evergreen shrubland } \\
\text { compositional group }\end{array}$ & $447 \cdot 25$ & 0.25 \\
\hline 29 & Dry prairie (Xeric-mesic) ecological complex & 1843.19 & 1.05 \\
\hline 30 & Gallberry/saw palmetto shrubland compositional group & 4111.66 & 2.33 \\
\hline 31 & Brazilian pepper shrubland & 89.34 & 0.05 \\
\hline 32 & Dwarf mangrove ecological complex & 676.77 & 0.38 \\
\hline 33 & Coastal strand & 74.09 & 0.04 \\
\hline 34 & Groundsel-tree/marsh elder tidal shrubland & 25.96 & 0.01 \\
\hline 35 & Xeric scrubland & 651.51 & 0.37 \\
\hline 36 & St Johns wort shrubland compositional group & 119.44 & 0.07 \\
\hline 37 & $\begin{array}{l}\text { Saturated-flooded cold-deciduous and mixed } \\
\text { evergreen/cold-deciduous shrubland ecological complex }\end{array}$ & $3516 \cdot 91$ & 2.00 \\
\hline 38 & Saltwort/Glaswort ecological complex & 111.37 & 0.06 \\
\hline 39 & Graminoid dry prairie ecological complex & 499.58 & 0.28 \\
\hline 40 & Sea oats dune grassland & $20 \cdot 38$ & 0.01 \\
\hline 41 & Wiregrass grassland & $44 \cdot 11$ & 0.03 \\
\hline 42 & Graminoid emergent marsh compositional group & 2364.61 & 1.34 \\
\hline 43 & Sawgrass marsh & 6101.09 & 3.46 \\
\hline 44 & Spikerush marsh & $200 \cdot 12$ & 0.11 \\
\hline 45 & Muhly grass marsh & 917.68 & 0.52 \\
\hline 46 & Cattail marsh compositional group & 253.36 & 0.14 \\
\hline 47 & Salt marsh ecological complex & $196 \cdot 83$ & 0.11 \\
\hline 48 & Sand cordgrass grassland & 136.38 & 0.08 \\
\hline 49 & Black needle rush marsh & $717 \cdot 06$ & 0.41 \\
\hline 50 & Saltmarsh cordgrass marsh & 613.91 & 0.35 \\
\hline 51 & Saltmeadow cordgrass/salt grass salt marsh & 1.78 & 0.00 \\
\hline 52 & Sparsely wooded wet prairie compositional group & 89.02 & 0.05 \\
\hline 53 & Dwarf cypress prairie & 697.71 & 0.40 \\
\hline 54 & Temperate wet prairie & 633.11 & 0.36 \\
\hline 55 & Maidencane marsh & 194.92 & 0.11 \\
\hline 56 & Forb emergent marsh & 1571.51 & 0.89 \\
\hline 57 & Water lily or floating leaved vegetation & $626 \cdot 15$ & 0.36 \\
\hline 58 & Periphyton & 0.00 & 0.00 \\
\hline
\end{tabular}


Table 2. Continued

\begin{tabular}{llrr}
\hline Code & Class name & Area $(\mathrm{sq} \mathrm{km})$ & \% Total \\
\hline 59 & Sand, beach & 256.32 & 0.15 \\
60 & Bare soil/clearcut & 4721.47 & 2.68 \\
61 & Pavement, roadside & 390.97 & 0.22 \\
62 & Urban & 4088.33 & 2.32 \\
63 & Urban residential & 6709.47 & 3.81 \\
64 & Urban open/others & 1904.26 & 1.08 \\
65 & Agriculture & 20950.22 & 11.89 \\
66 & Pasture/grassland/agriculture & 14882.27 & 8.45 \\
67 & Agriculture/groves/ornamental & 4238.82 & 2.41 \\
68 & Agriculture/confined feeding operation & 271.86 & 0.15 \\
69 & Extractive & 1127.16 & 0.64 \\
70 & Recreation & 434.65 & 0.25 \\
71 & Cloud & 202.95 & 0.12 \\
& Total & 176187.56 & \\
\hline
\end{tabular}

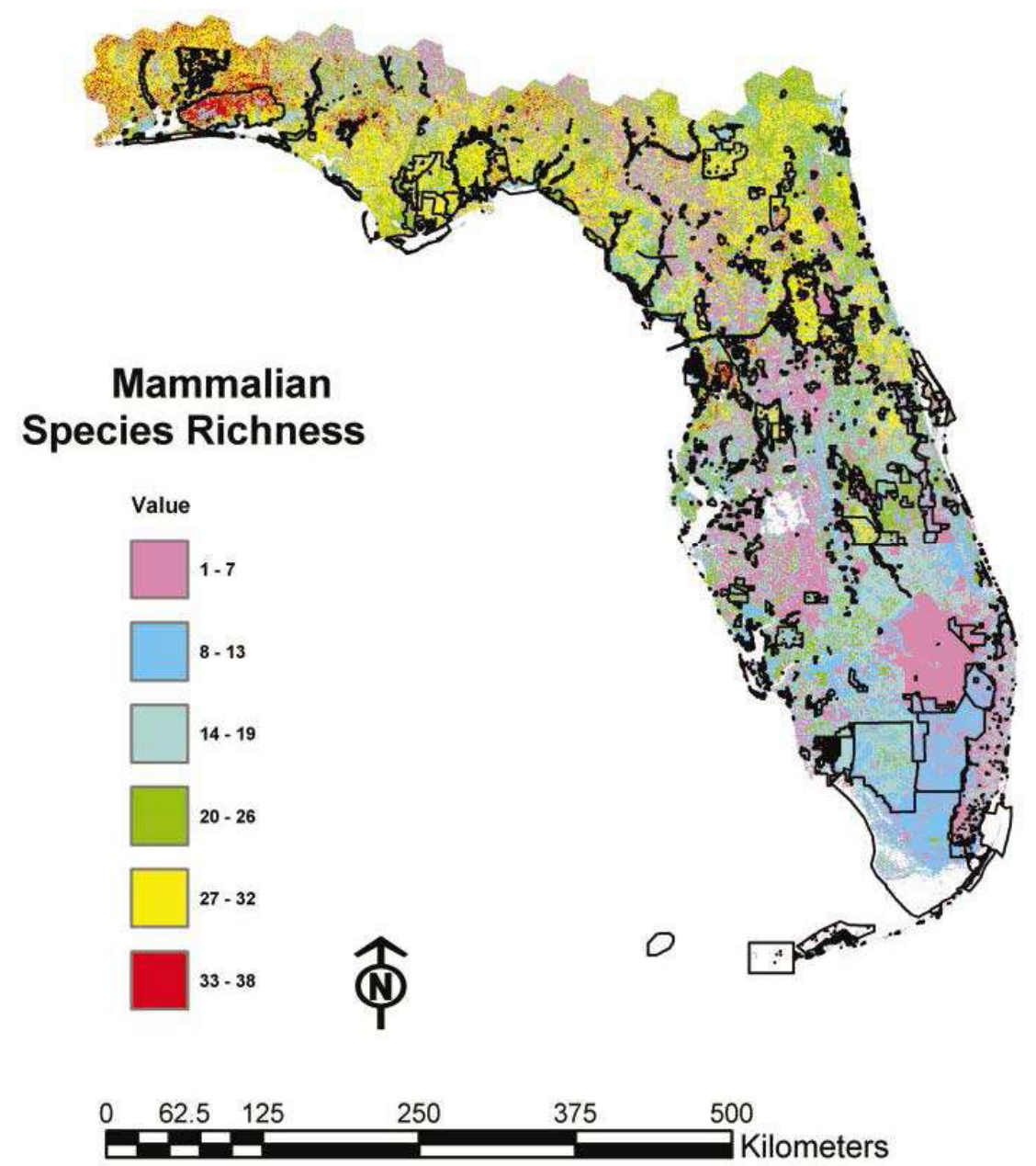

Figure 4. Mammalian species richness. Conservation land boundaries are overlaid as black lines.

Mammal species richness is high throughout north Florida and the panhandle. In particular, unprotected areas of high species richness include both coasts of north Florida and the panhandle, the lands between Eglin Air Force Base and Blackwater River State Forest, and the lands between Osceola National Forest, Camp Blanding Military Reservation, and Ocala State Forest. 


\section{Birds}

Median bird diversity as modeled is between 52 and 56 species. Bird species richness is highest in swamp forests, pasture, agriculture and urban classes. Because our interest is primarily in species richness

Table 3. Summary by land stewardship status area. Status categories are defined in Table 1

\begin{tabular}{lrr}
\hline & Area $(\mathrm{sq} \mathrm{km})$ & \% of State \\
\hline Status 1 & 314.23 & 0.19 \\
Status 2 & 16609.87 & 9.79 \\
Status 3 & 21314.42 & 12.57 \\
Status 4 & 131349.29 & 77.45 \\
Total & 169587.81 & 100.00 \\
\hline
\end{tabular}

within natural areas, Figure 5 illustrates bird species richness when urban and agriculture other than pasture/grassland are excluded. All forested classes are associated with high counts of bird species though the swamp forest classes (including cypress and bay) are significantly higher than other forest land covers. As with the mammals, there is evidence of decreasing richness along a north-south gradient. An exception to this gradient is an area of high avian richness in extreme southwestern Florida.

State and federal lands such as Eglin Air Force Base, Withlacoochee State Forest, Osceola National Forest, Apalachicola National Forest, Fakahatchee Strand State Park, and Big Cypress National Preserve provide habitat for a high diversity of avian species. Unprotected areas of avian diversity,

\section{Avian Species Richness}

Value

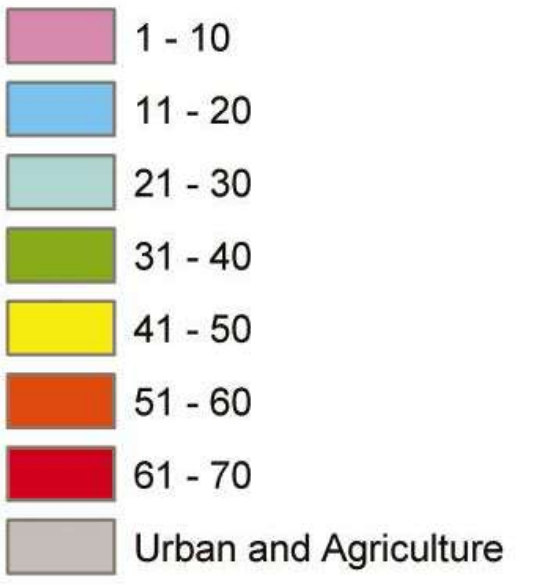

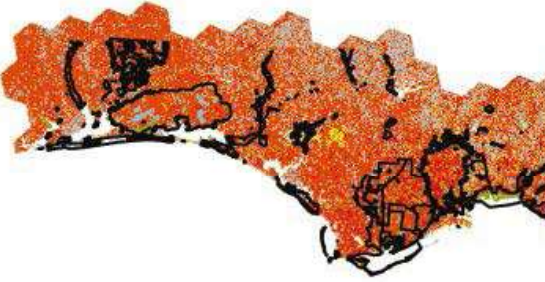
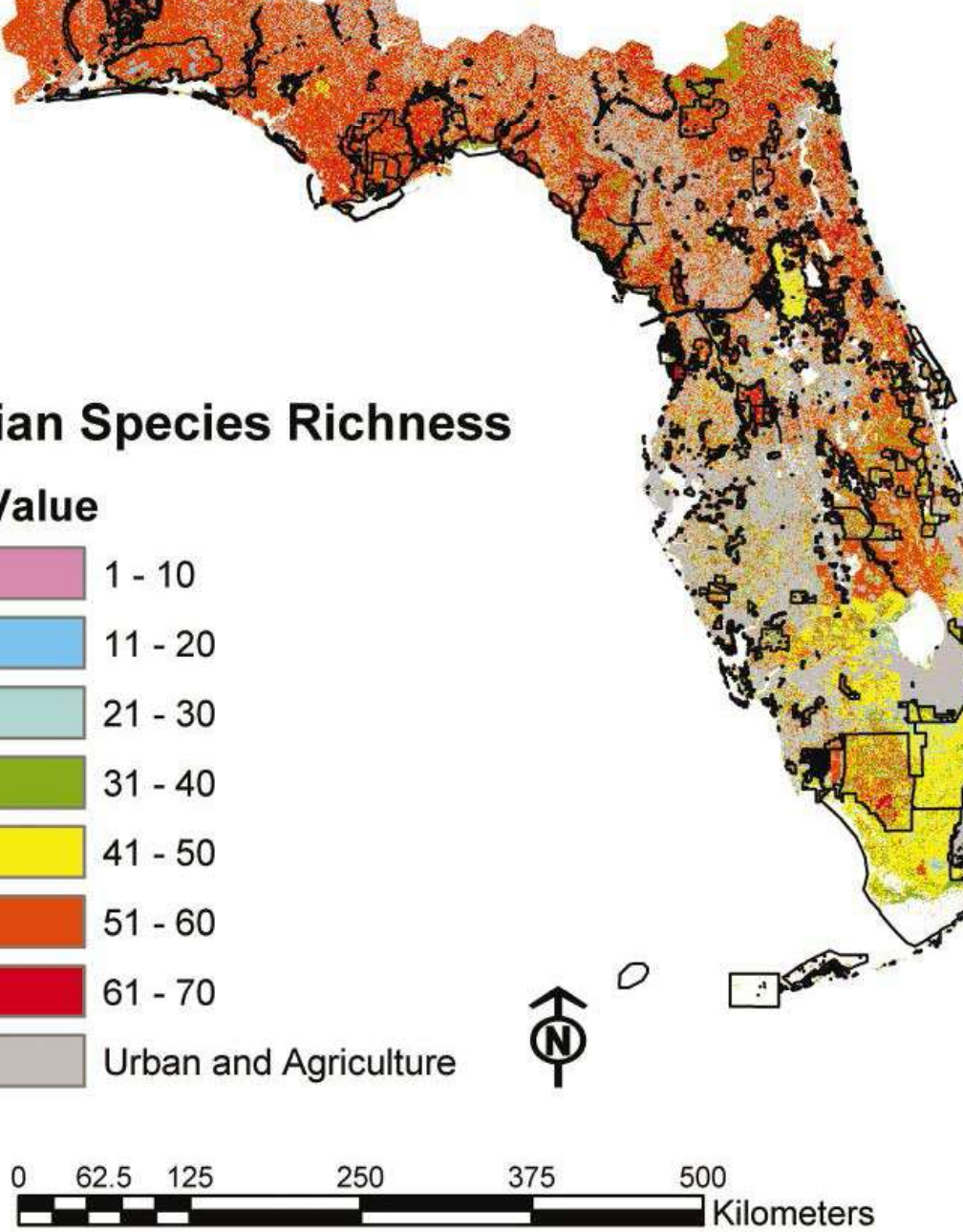

Figure 5. Avian species richness excluding urban and crop land covers. Conservation land boundaries are overlaid as black lines. 
in order of species richness, exist along both coasts of north Florida, east central Florida, and the pasture lands of the Immokalee Rise (southwest Florida) and north of the Caloosahatchee River.

\section{Reptiles and amphibians}

The highest modeled richness of reptiles and amphibians is associated with open water, swamp forests, and sandhill land covers. Species diversity for hepetofauna is highest in the panhandle and decreases in central and southern Florida, mirroring the broad pattern displayed by the other vertebrate taxa. High richness habitats in central to northern Florida support 40 to species. In southern Florida, the maximum species richness is in the mid-thirties.
Figure 6 presents reptile and amphibian species richness for all land covers excluding anthropomorphic (crops and urban) development.

Eglin Air Force Base, Apalachicola National Forest, and the Big Bend Wildlife Management Area are examples of some of the highest reptile and amphibian diversity in protected areas. The bottomland and wet forested areas of the Gulf Coast appear to provide the best opportunities for additional protection of species richness.

\section{Ants}

Across the Florida peninsula, potential ant species richness, like vertebrates, displays a pattern of highest richness to the northern and decreasing

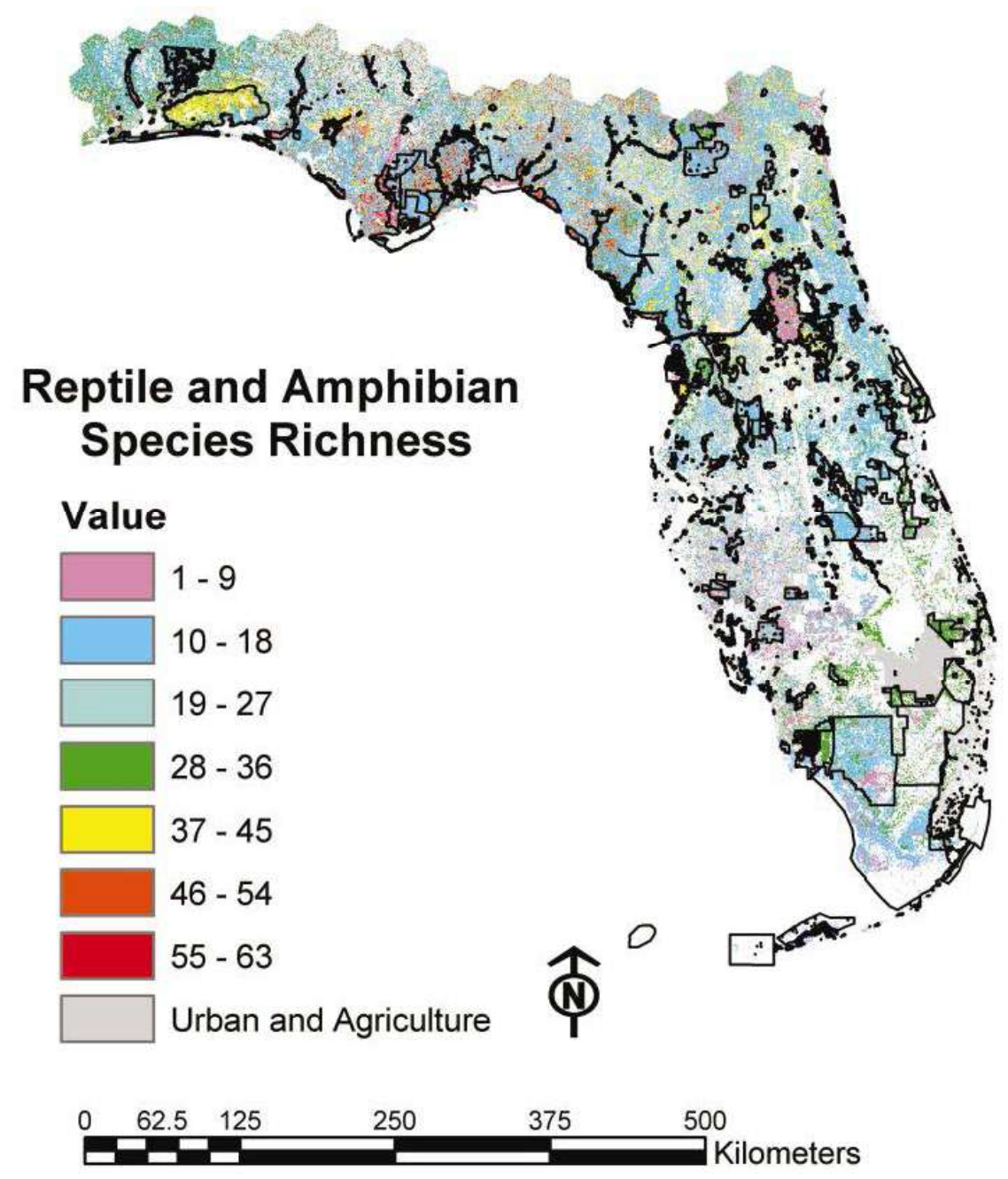

Figure 6. Reptile and amphibian species richness excluding urban and crop land covers. Conservation land boundaries are overlaid as black lines. 
richness towards the southern peninsula. This is probably due to decreasing habitat diversity and an increasing prevalence of saturated and inundated habitat types. Species composition also changes across this gradient, with an increasing prevalence of species of West Indian origin in southern Florida concomitant with a decreasing important of species of Northern American origin.

Modeled ant species richness in southern Florida is highest in the pine rocklands, southern Florida slash pine, and tropical hardwoods. Pine communities continue to be an important habitat for ants in central and northern Florida. The sand pine and pine/oak land covers in northern Florida are suitable habitat for the highest numbers of ant species in the state (Figure 7).

The highest modeled ant species richness is within the xeric central Florida sandhill and sand pine communities protected by Ocala National Forest and Withlacoochee State Forest. The highest unprotected diversity is in the forested land covers of north Florida. In particular, the lands between and adjacent to Ocala National Forest, Camp Blanding Military Reservation and Paynes Prairie State Preserve.

\section{Butterflies and skippers}

Butterflies and skippers are the only group modeled that have the highest diversity in southern Florida. The Everglades and Big Cypress National Preserve are suitable habitat for 40 to 50 butterfly species. Everglade's marsh north of Timiami Trail has species richness counts as high as 56. Maximum species richness in northern Florida is in the teens, except for graminiod marsh land covers where

\section{Ant Species Richness}

\section{Value}
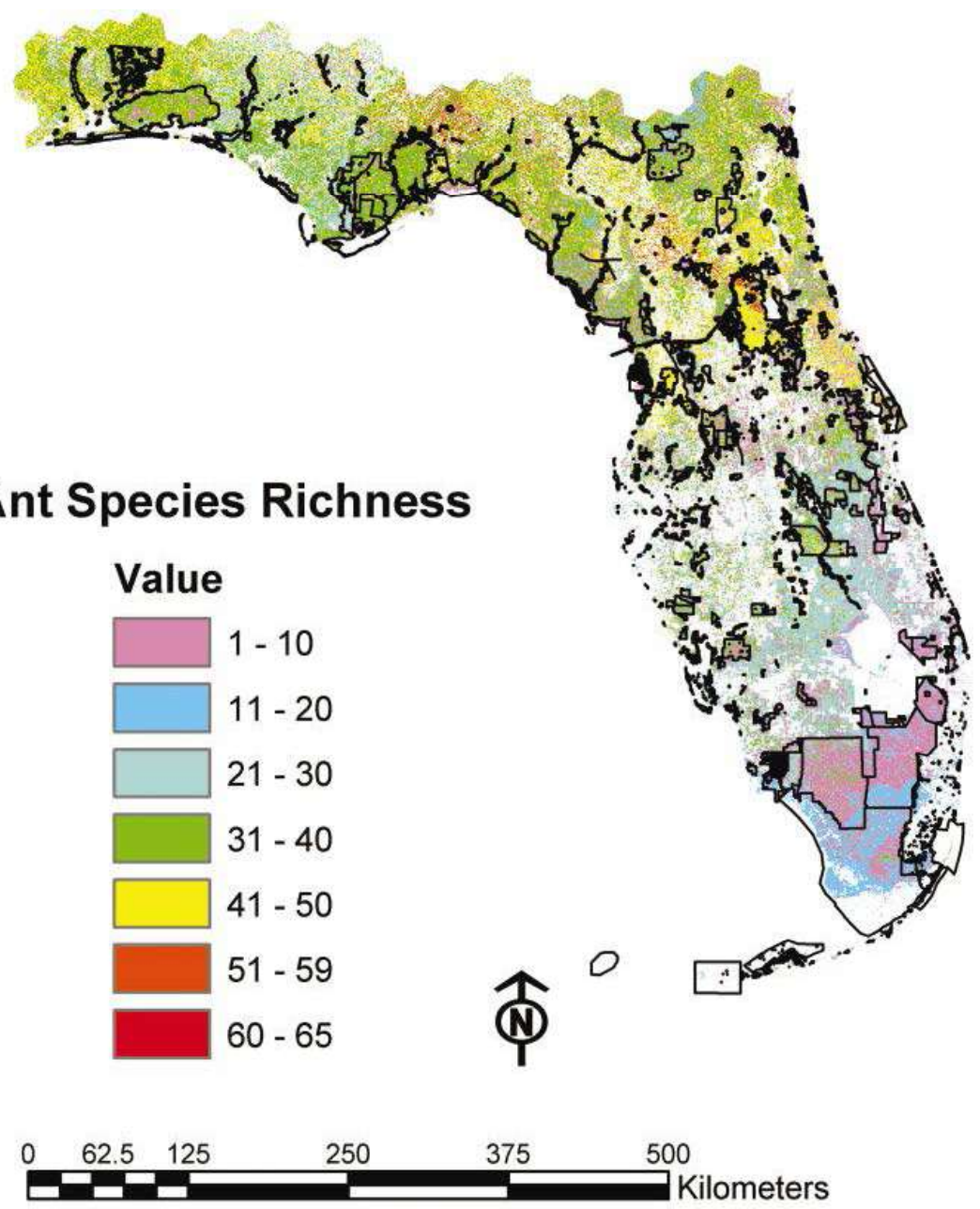

Figure 7. Ant species richness. Conservation land boundaries are overlaid as black lines. 


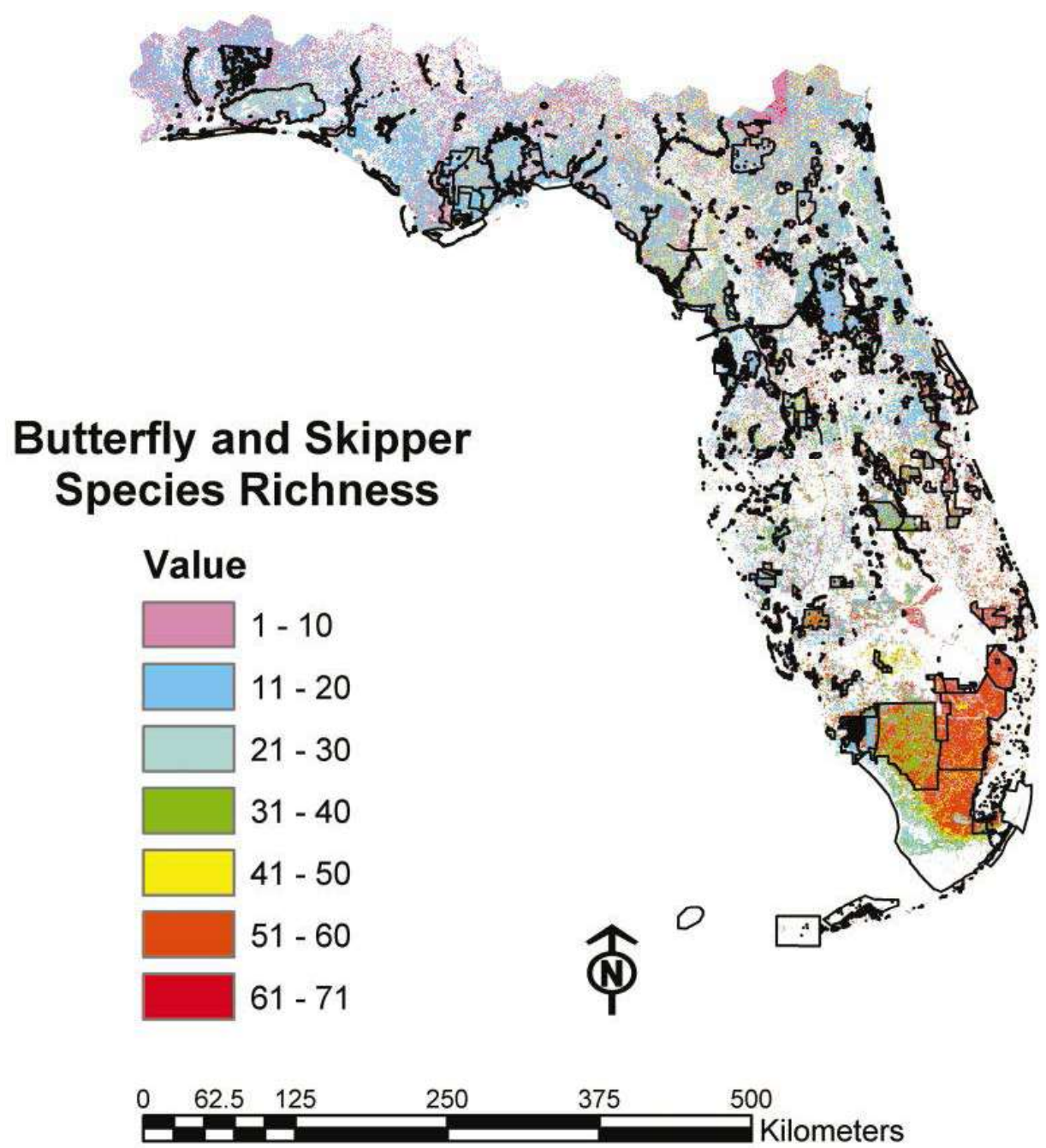

Figure 8. Butterfly and skipper species richness. Conservation land boundaries are overlaid as black lines.

the number of butterfly species can be in the thirties and even the sixties in restricted small areas (Figure 8).

At the state level, areas of high butterfly diversity all appear to be within the confines of conservation lands. The largest areal extent is in south Florida with smaller pockets of high species richness in central Florida and at the mouth of the Apalachicola River.

\section{All species combined}

Total species richness (mammals, birds, reptiles, amphibians, ants, and butterflies combined) is presented in Figure 9. Overall richness of all taxa mapped follows a north-south gradient, with highest richness in the north and decreasing richness southward. Highest species richness is associated with swamp forest and sandhill land covers. In southern Florida, pine communities provide habitat for the largest number of species. Species richness overall follows the pattern of most of the individual groups, with highest diversity in the panhandle of Florida.

Status 1 conservation lands have a very high diversity of species, but because of their small extent, the species all represent a tiny proportion of the state's distribution. The occurrence of species within the differently ranked conservation lands closely reflects the relative proportion of the status category in the state. 


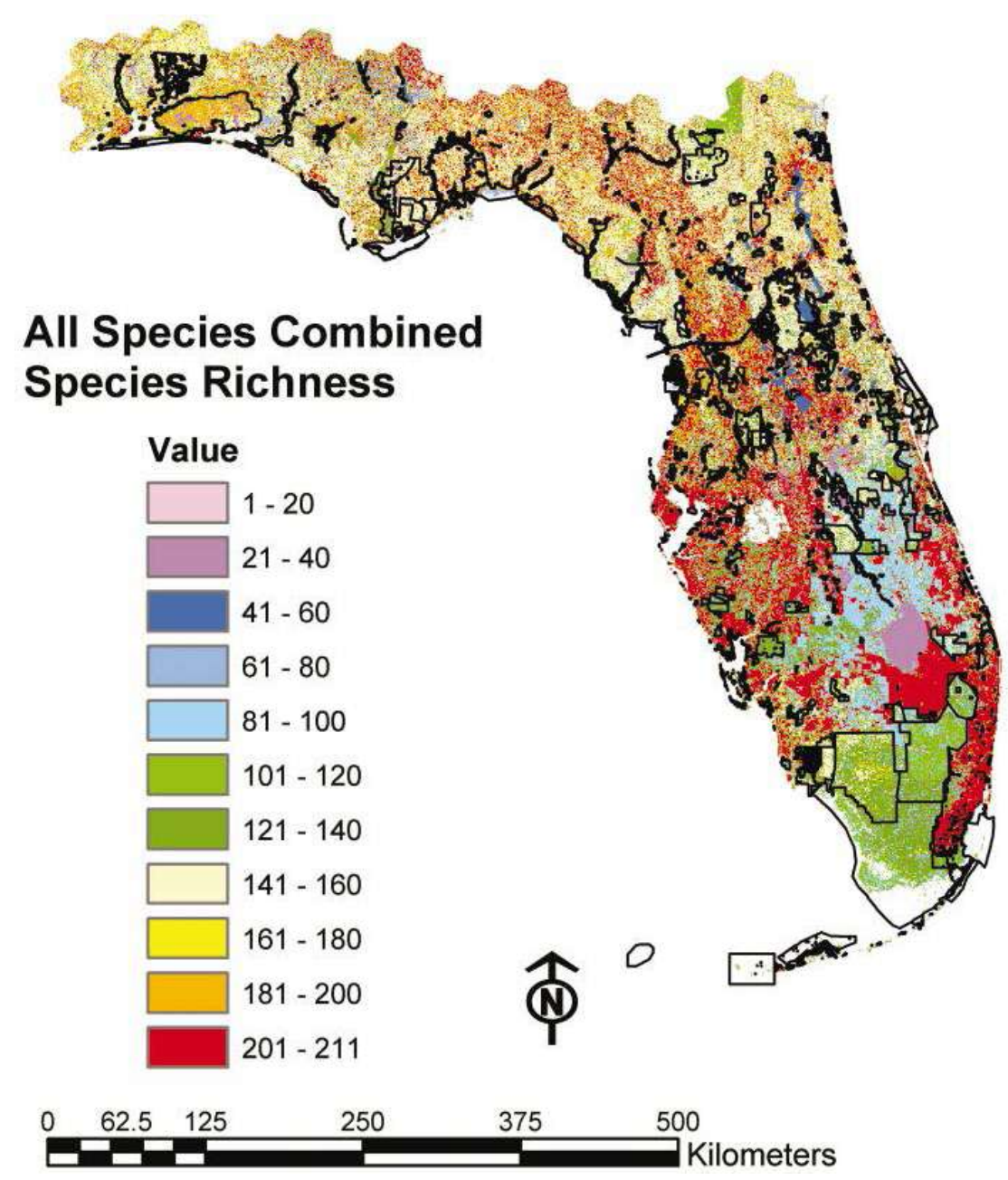

Figure 9. Total Species richness. Conservation land boundaries are overlaid as black lines.

\section{Discussion}

The FL-GAP project provides a tool for setting priorities for biodiversity conservation. This type of information can be used to assist in prioritization of land acquisition, restoration, and management actions as well as evaluating the potential effects of development and other changes in land use. Application is most relevant at regional levels given the broad scale patterns of vegetation and potential habitat distributions for a large number of species the technique employs. The land cover classification provides a regional perspective of land cover patterns, juxtapositions and occurrences in the landscape. Use in smaller scale applications should be limited to analyses of parcel context within the regional landscape. We recommend that application in any project smaller than regional scale be carefully reviewed and revised appropriate to the scale required for the objectives of the project.

Because all of the terrestrial vertebrates of the state have been mapped along with two invertebrate groups, these products offer natural resource managers a tool for multi-species protection relevant to allocation of land resources. Potential habitats in the spatial databases can be used to distinguish species communities by identifying species sharing the same habitat requirements or species sharing a common area, perhaps within a matrix of diverse habitats. The US Fish and Wildlife Service in south Florida, for example, is using the FL-GAP models to help answer questions about how protection of potential habitat for individual T\&E species can contribute to the protection of potential habitat for all other terrestrial vertebrates. 
While these models are not intended for evaluation within small, site-specific projects, intelligent ecological restoration and permitting requires spatially-explicit knowledge of conditions proximate and regional to project sites. Species often are dependent on habitat areas larger than those impacted by a single project (Gosselink et al., 1990) and the spatial patterns of habitat adjacent to a specific site may as important as the within-site habitat (Pearlstine et al., 1997; Saunders et al., 1991). Examples include determination of areas suitable for viable and sustainable populations (habitat and risk assessment), areas of socioeconomic and environmental conflict, and optimization of development footprints to protect natural systems.

An alternative to the species-habitat models used in FL-GAP are occurrence models that select habitat based on areas of known species occurrence. These two forms of habitat modeling are complimentary. When results of the two approaches are compared, areas of overlap provide robustness to the analysis, while areas of little or no overlap will indicate limitations in the data layers or areas where additional information is needed to better model the species. Areas of the species-habitat models that do not overlap with occurrence data may also draw attention to potential areas for species reestablishment. In Florida, both the Florida Fish and Wildlife Conservation Commission and The US Fish and Wildlife Service are involved in species reestablishment activities.

We expect that the FL-GAP models overestimate the spatial extent of most species' distributions. The vertebrate, butterfly, and ant habitat-affinity models rely on associating the potential for a species' presence with specific land covers. The mammal models are refined to some extent by consideration of minimum contiguous area to maintain a viable population. Regardless, there are many factors in habitat selection that have purposefully not been considered because of resource and time limitations, the availability of statewide data, and/or inadequate knowledge of species response to the environmental variables. Reptiles and amphibians are an example of a group that may be responding to soil type, litter accumulation, moisture conditions and proximity to streams rather than directly to vegetation composition. Other parameters can readily be identified for other species or species groups including land cover structure (such as age, height and layering of vegetation, presence of snags), and the juxtaposition of desirable vegetation cover to other desirable cover types (e.g., foraging versus nesting) or undesirable features (e.g., roads or heavy recreational activity).

\section{Conclusions}

The Fl-Gap mapping of Florida species richness clearly suggest a high diversity of most of the taxa in north Florida and in particular, the panhandle of the state. Swamp, mixed pine/oak, sandhill scrub and longleaf pine, and flatwoods pine all contribute to the wildlife species richness of this area of the State. Additionally, for many taxa this region is an area of overlap of species with northern affinities and species with southern affinities. The release of findings from a joint project of The Nature Conservancy and the Association of Biodiversity Information, 'Precious Heritage: The Status of Biodiversity in the United States' (Stein et al., 2000) corroborates the importance of Florida panhandle biodiversity using a different approach to modeling diversity. The Precious Heritage project uses state Heritage Program data to map species richness of an area weighted by relative rarity of the species as measured by how restricted its distribution is. The analysis pinpoints the panhandle of Florida as one of the six most significant areas of biodiversity in the United States.

In southern Florida, with the exception of butterflies and skippers, forested classes (swamp and pine rockland) appear to support the highest diversity. In central Florida, species-rich classes include swamp, pine flatwoods, xeric scrub, and sandhills. It is important to note that xeric scrub in the south central Florida region is underrepresented in the land cover classification and resulting in lower species richness in much of this area than would otherwise be the case.

The pine flatwood, xeric pine, and xeric scrub communities in Florida are major contributors to the species diversity of the state and are some of the most threatened because of changing fire regimes and their suitability for development or slash pine farming. The unique pine rocklands of south Florida are threatened by exotic invasive vegetation. In northern Florida, the sandhill scrub and longleaf pine habitats of Eglin Air Force Base are protected by an aggressive natural resource management plan that includes continuing research, adaptive management, and longleaf pine ecosystem restoration. Ocala National Forest and Withlacoochee State Forest in central Florida are two additional large areas of xeric community conservation. In other areas of north and central Florida loss of these valuable upland habitats is progressing steadily.

The Fl-Gap biodiversity project has compiled a baseline for predicting species distributions and richness statewide that must now be refined with 
studies scaling from landscape analyses to onthe-ground validation. Landscape context refinements of the species models should address issues of sustainability and resilience. Key questions that need to be answered include: (1) How much contiguous and non-contiguous habitat is required to sustain wildlife populations into the future? (2) How will configurations of landscape elements maintain habitat in dynamic systems impacted by natural processes such as fire and hurricane disturbance? (3) What factors influence the process of animals moving among landscape elements? (4) How does the proximity of different land covers change the viability of selected habitats? (5) How do results of this analysis change at different scales, including grain (the minimum unit of measurement) and extent (the size of the study area and/or length of time over which it is studied)? (6) Finally, it is critical to incorporate the temporal change in the landscape for the applications to be meaningful. If we stop at conservation of current known 'hot spots' of species richness, we risk great loss as dynamics in the environment shift ecological conditions.

Fl-Gap is expected to be an on-going project. This report is only the first iteration in a process of learning to adapt and use a new, ecologically-based National Vegetation Classification Scheme to statewide mapping and apply those results as well as other appropriate mapped data sources to a measure of Florida's biodiversity and potentials for conservation.

Future iterations of GAP biodiversity measures will increasingly incorporate parameters of biological integrity and a wider range of species taxa. The experiences gained and data compiled by this and other states engaged in the US National Gap Analysis Program, increasing availability of georeferenced, broad extent mapped biological and geological data, improved earth-sensing technologies, and the dissemination of better approaches for landscape modeling and statistical analysis will continue to strengthen the scientific basis for natural resource decisions in the state of Florida.

\section{Acknowledgments}

This study was funded in part by the US Geological Survey, The Florida Fish and Wildlife Conservation Commission, Eglin Air Force Base, DOD, and the Florida Agricultural Experiment Station journal series manuscript number R-08162.

Significant contributions of time were also made by Florida Natural Areas Inventory, Coastal Services Center, NOAA, Center for Coastal Geology,
USGS, and many individuals with particular thanks to Nick Ansay, Joe Aufmuth, Valentina Boycheva, Michael Cook, Steve Cox, Michael Frankenberger, Karen Garren, E. Paul Gonzalez, Lisa Ojanen, and Roger Winstead.

\section{References}

Allen, C. R., Pearlstine, L. G. and Kitchens, W. M. (2001). Modeling viable mammal populations in gap analyses. Biological Conservation 99, 135-144.

Blair, F. W. (1935). Some mammals of southern Florida. American Midland Naturalist 16, 801-804.

Bureau of Census (1960). Census 1960: Summary of File 1: 100 Percent Data. Department of Commerce, Viewed on 20 November 2001.

Bureau of Census (1990). Census 1990: Summary of File 1: 100 Percent Data. Department of Commerce, Viewed on 20 November 2001.

Bureau of Census (2000). Census 2000: Summary of File 1: 100 Percent Data. Department of Commerce, Viewed on 20 November 2001.

Chapman, J. A. and Feldhamer, G. A. (1982). Wild mammals of North America. Baltimore, MD: The Johns Hopkins University Press.

Cox, J., Kautz, R., MacLaughlin, M. and Gilbert, T. (1994). Closing The Gaps In Florida's Wildlife Habitat Conservation System. Tallahassee, FL: Florida Game and Fresh Water Fish Commission, Office of Environmental Services.

Crist, E. and Cicone, R. (1984). Applications of the tasseled cap concept to simulated Thematic Mapper data, Photogrammetric Engineering and Remote Sensing, 50, 343-352.

ERDAS (1999). ERDAS Field Guide. 5th Edition. ERDAS, Inc. Atlanta, GA.

Florida Game and Freshwater Fish Commission (1997). Official list of endangered and potentially endangered fauna and flora in Florida. Tallahassee (FL): Florida Game and Freshwater Fish Commission.

Gosselink, J. G., Lee, L. C. and Muir, T. A. (eds) (1990). Ecological Processes and Cumulative Impacts: Illustrated by Bottomland Hardwood Wetland Ecosystems. Chelsea, MI: Lewis Publishers, Inc.

Grossman, D., Goodin, K. L., Li, X., Wisnewski, C., Faber-Langendoen, D., Anderson, M., Sneddon, L., Allard, D., Gallyoun, M. and Weakley, A. (1994). Standardized national vegetation classification system. Report by The Nature Conservancy and Environmental Systems Research Institute for the NBS/NPS Vegetation Mapping Program. Denver, Colorado: National Biological Service.

Hamilton, W. J. (1941). Notes on some mammals of Lee County, Florida. American Midland Naturalist 25, 686-691.

Humphrey, S. R. (ed) (1992). Rare and Endangered Biota of Florida: Mammals. Gainesville, FL: University of Florida Press.

Jennings, M. D. (1993). Natural terrestrial cover classification: Assumptions and definitions. Gap Analysis Technical Bulletin 2. Idaho Cooperative Fish and Wildlife Research Unit, Moscow, ID: University of Idaho. 
Jenson, J. R. (1996). Introductory Digital Image Processing: A Remote Sensing Perspective, Prentice Hall, Upper Saddle River, NJ.

Kale, H., Pranty, B., Stith, B. and Biggs, C. (1999). Atlas of Breeding Birds of Florida. The Florida Audubon Society.

Layne, J. (1984). The land mammals of South Florida. In: Environments of South Florida, Past and Present II, (Gleason, P. J. ed.), pp. 269-295. Coral Gables, FL: Geological Society.

Moler, P. (1999). Statewide Occurrence Database, Florida Game and Fresh Water Fish Commission, www.npwrc.usgs.gov/resource/distr/lepidbflyusa/ blflyusa.htm.

Opler, P. (1999) Personal communication.

Pearlstine, L., Brandt, L. A., Mazzotti, F. J., Kitchens, W. M. (1997). Fragmentation of pine flatwood and marsh communities converted for ranching and citrus. Landscape and Urban Planning 38, 159-169.

Pearlstine, L. and McKerrow, A. (1999). Compositional Groups and Ecological Complexes: A Method for Alliance-Based Vegetation Mapping. In Gap Analysis Bulletin (E. Brackney and M. Jennings, eds), v. 7, pp. 16-17. Moscow, Idaho: U.S. Geological Survey, Biological Resources Divsion.

Pearson, P. G. (1954). Mammals of Gulf Hammock, Levy County, Florida, American Midland Naturalist 51, 468-480.

Pournelle, G. H. (1950). Mammals of a north Florida swamp. Journal of Mammalogy 31, 310-319.

Saunders, D. A., Hobbs, R. J. and Margules, C. R. (1991). Biological consequences of ecosystem fragmentation: a review. Conservation Biology 5, 1-32.

Scott, J. M., Csuti, B., Jacobi, J. D. and Estes, J. E. (1987). Species richness. Bioscience 37, 782-788.

Scott, J. M. and Jennings, M. D. (eds) (1994). A handbook for Gap Analysis. Moscow, Idaho: Idaho Coopera- tive Fish and Wildlife Research Unit, University of Idaho.

Scott, J. M., Davis, F., Csuti, B., Noss, R., Butterfield, B., Groves, C., Anderson, H., Caicco, S., D'Erchia, F., Edwards, Jr., T. C., Ulliman, T. and Wright, G. (1993). Gap analysis: A geographic approach to protection of biological diversity. Wildlife Monographs 123.

Shaffer, M. L. (1981). Minimum population sizes for species conservation. BioScience 31, 131-134.

Sherman, H. B. (1952). The list and bibliography of the mammals of Florida, living and extinct. Quarterly Journal of the Florida Academy of Sciences 15, 100-126.

Slaymaker, D. M., Jones, K. M. L., Griffin, C. R. and Finn, J. T. (1996). Mapping deciduous forest in Southern New England using aerial videography and hyperclustered multi-temporal Landsat TM imagery. In Gap Analysis, A Landscape Approach to Biodiversity Planning, (J. M. Scott, Tear, T. H. and Davis, F. W. eds). pp. 87-101. Bethesda, MD: American Society of Photogrammetry and Remote Sensing.

Starner, B. A. (1956). Notes on the mammals in three habitats in North Florida. Quarterly Journal of the Florida Academy of Sciences 19, 153-156.

Stein, B., Kutner, L. and Adams, J. (eds). (2000). Precious Heritage, The Status of Biodiversity in the United States. Oxford University Press.

The Nature Conservancy. (1997). International Classification of Ecological Communities, Terrestrial Vegetation of The Southeastern United States. Chapel Hill, NC: The Nature Conservancy.

White, D., Kimerling, J. and Overton, S. (1992). Cartographic and geometric components of a global sampling design for environmental monitoring. Cartography and Geographic Information Systems 19, 5-21.

Wojcik, D. (1999). U.S. Department of Agriculture, Gainesville Florida, unpublished data. 